\title{
ResearchArticle
}

\section{Studies on antibacterial activity of some aqueous plant extracts against Ralstonia solanacearum causing bacterial wilt and brown rot of potato}

\author{
G. BISWAL
}

\section{SUMMARY}

The aqueous leave/flower/seed extracts were prepared from locally grown twenty plants in Depatment of Plant Pathology, Orissa University of Agriculture and Technology in 2009-10 and were tested following inhibition zone technique in vitro against Ralstonia solanacearum causing bacterial wilt and brown rot of potato. The result indicated that all the aqueous plant extracts exhibited antibacterial property. Maximum zone of inhibition (10mm) was observed in leaf extract of Musa paradisica and flower extract of Nerium indicum while lowest zone of inhibition $(6.68 \mathrm{~mm})$ was observed in leaf extract of Ocimum sanctum and flower extract of Ixora coccinea

Key Words : Aqueous plant extracts, Antibacterial activity, Bacterial wilt, Brown rot

How to cite this article : Biswal, G. (2015). Studies on antibacterial activity of some aqueous plant extracts against Ralstonia solanacearum causing bacterial wilt and brown rot of potato. Internat. J. Plant Sci., 10 (1): 1-6.

Article chronicle : Received : 02.06.2014; Revised : 01.11.2014; Accepted : 15.11.2014

\section{AUTHOR FOR CORRESPONDENCE}

G. BISWAL, Department of Plant Pathology, College of Agriculture, Orissa University of Agriculture and Technology, BHUBANESWAR (ODISHA) INDIA

Email: gayatribiswal1965@gmail.com 